\title{
An Unexpectedly High Frequency of Hypergalactosemia in an Immigrant Bosnian Population Revealed by Newborn Screening
}

\author{
SUSANNE REICH, JULIA HENNERMANN, BARBARA VETTER, LUITGARD M. NEUMANN, \\ YOON S. SHIN, ARIANE SÖLING, EBERHARD MÖNCH, AND ANDREAS E. KULOZIK \\ Children's Hospital [S.R., J.H., B.V., E.M., A.E.K], Department of Human Genetics [L.M.N.], Charité, \\ Campus Virchow, Humboldt University, D-10247 Berlin, Germany; Children's Hospital, \\ Ludwig-Maximilian-University, D-80337 Munich, Germany [Y.S.S.]; Department of Neurosurgery, \\ Martin-Luther-University, D-06097 Halle, Germany [A.S.]
}

\begin{abstract}
ABS
In galactokinase (GALK) deficiency, galactose cannot be
phosphorylated into galactose-1- phosphate, which leads to cat-
aract formation. Neonatal screening for hypergalactosemia in
Berlin has been performed by thin-layer chromatography since
1978, which detects classical galactosemia and GALK defi-
ciency. Until 1991, GALK deficiency has not been identified in
a total of $\approx 260,000$ samples. In contrast, from 1992 to 1999 , nine
patients were detected in a total of $\approx 240,000$ screened newborns.
One Turkish patient was homozygous for two novel S142I/
G148C GALK mutations in close proximity to the putative
ATP-binding site of the enzyme. The other eight children were
born to five families belonging to the Bosnian refugee population
consisting of approximately 30,000 individuals who have arrived
\end{abstract}
GALK is the first of three enzymes involved in the conversion of galactose to glucose. It catalyzes the phosphorylation of galactose to galactose-1-phosphate. When infants with homozygous GALK deficiency are fed with milk, galactose accumulates and is converted to galactitol. Within weeks, the deposition of galactitol in the lens leads to cataract formation (1-3), which may also affect heterozygous carriers, albeit at a later age (4-6). Importantly, the development of cataracts can be avoided if a galactose-free diet is initiated early (7).

GALK deficiency is inherited in an autosomal recessive fashion and the incidence of the disease has been estimated to be as low as $1: 100,000$ to $1: 1,000,000$ in most populations (8, 9). A higher frequency has been suggested in southeastern Europe generally and in Romani in particular (10-12). The human galk gene maps to chromosome 17q24 and codes for a protein of 392 amino acids and a molecular mass of $42 \mathrm{kD}$ (13). The gene contains eight exons and spans about $7.3 \mathrm{~kb}$

Received January 15, 2001; accepted June 28, 2001.

Correspondence: Andreas E. Kulozik, M.D., Ph.D., Department of Pediatric Oncology, Hematology and Immunology, University of Heidelberg, Im Neuenheimer Feld 150, D-69120 Heidleberg, Germany; e-mail: andreas_kulozik@med.uni-heidelberg.de

Supported by SHS-Gesellschaft für klinische Ernährung mbH. in Berlin since 1991. In two of these families, GALK deficiency was subsequently diagnosed in siblings who had cataract surgery at 4 and $5 \mathrm{y}$ of age, respectively. In all these 10 Bosnian patients, a homozygous P28T mutation located near the active center of the enzyme was identified. We propose that neonatal screening of populations with a significant proportion of Bosnians and possibly other southeastern Europeans, e.g. Romani, should be particularly directed toward GALK deficiency, an inborn error of metabolism that is readily amenable to effective treatment. (Pediatr Res 51: 598-601, 2002)

\section{GALK, galactokinase}

(14). The galk gene has also been cloned from bacteria [Escherichia coli (15)] and yeast [Saccharomyces cerevisiae and Streptomyces lividans (16, 17)]. All known galactokinases share three highly conserved regions containing a GALK signature sequence encoded by exon $1(13,15)$, and two separate ATP-binding motifs encoded by exons 3 and 7 (15, 16, 18).

Complementation analyses in yeast suggested a second putative human galk locus that was designated $g k 2$ (19). The $g k 2$ gene maps to chromosome 15 and codes for a protein with a $34.6 \%$ sequence identity with GALK1. However, only GALK1 exhibits significant enzyme activity in transfected mammalian cells, which indicates that galkl represents the only functional human gene (20). In GALK deficiency, 18 different mutations have been described to date.

Most of the reported mutations were private mutations found in single families $(13,21,22)$, with the exception of two mutations: the Q382X mutation found in six Costa Rican families (22) and the P28T missense mutation found in a Turkish newborn (22), as well as in five Romani families from Bulgaria, where a founder effect has been suggested (23). 
In this report, we describe an unexpectedly high incidence of GALK deficiency in the Berlin neonatal screening program since 1991. One patient of Turkish origin was homozygous for a novel mutant genotype characterized by two distinct base changes at codons 142 and 148, respectively. All other affected neonates were of Bosnian descent and carried the homozygous P28T mutation. Based on these results, we discuss the relevance of neonatal GALK deficiency screening.

\section{METHODS}

Screening for hypergalactosemia is included in the national neonatal screening program. Genotype analysis was performed as part of the routine diagnostic work-up after written informed consent was obtained from the parents of all probands.

Screening methods. Patients with GALK deficiency were identified by neonatal screening that is based on the detection of increased amounts of galactose in dried blood spots by thin-layer chromatography (23).

Measurements of enzyme activity. Quantitative estimation of enzymatic activity in erythrocytes of the patients and their parents was performed by monitoring the conversion of ${ }^{14} \mathrm{C}$ labeled galactose to $\left({ }^{14} \mathrm{C}\right)$-galactose-1-phosphate (24).

Mutation analysis. Genomic DNA of the probands, their parents, and normal controls were isolated from peripheral blood. DNA sequencing was performed using biotinylated amplification primers that have been described previously (13). For the separation of the double-stranded PCR products, Dynabeads (Dynal, Lake Success, NY, U.S.A.) were used (25). The presence of the P28T mutation was confirmed by AvaI restriction analysis of a 346-bp PCR fragment that was amplified from the genomic DNA. The S142I/G148C double mutation was confirmed by allele-specific oligonucleotide hybridization [S131I: 5'-TGGTGGTCAGCTCAGTGCC-3' (wild type) and 5'-TGGTGGTCATCTCAGTGCC-3' (mutation G 392 to T); G137C: 5'-CCCCTGGGGGGTGGCCTGT-3' (wild type) and 5'-CCCCTGGGGTGTGGCCTGT-3'(mutation G409 to T)].

\section{RESULTS}

Newborn screening for hypergalactosemia by thin-layer chromatography has been carried out in Berlin since 1978. Between 1978 and 1990, about 20,000 samples were analyzed annually. Since 1991 (1 y after the reunification of East and West Germany), this annual number increased to approximately 32,000 samples. Up to 1991 , GALK deficiency was not detected among 260,000 neonates. In contrast, between 1992 and 1999, increased galactose concentrations were found in 9

Table 1. Study of the galk gene in six families with GALK deficiency detected by newborn screening in Berlin, Germany

\begin{tabular}{ccccc}
\hline $\begin{array}{c}\text { Family } \\
\text { No. }\end{array}$ & $\begin{array}{c}\text { Country of } \\
\text { origin }\end{array}$ & $\begin{array}{c}\text { No. patients } \\
\text { detected }\end{array}$ & $\begin{array}{c}\text { Siblings with } \\
\text { cataracts }\end{array}$ & Mutation \\
\hline 1 & Bosnia & 2 & & P28T \\
2 & Bosnia & 2 & 1 & P28T \\
3 & Bosnia & 2 & & P28T \\
4 & Bosnia & 1 & & P28T \\
5 & Bosnia & 1 & 1 & P28T \\
6 & Turkey & 1 & & S142I, G148C \\
\hline
\end{tabular}

of 240,000 newborns (Table 1). The diagnosis of severe GALK deficiency was confirmed by demonstrating absent GALK activity in erythrocytes of the patients. One patient was Turkish and eight were born to 5 non-consanguineous Bosnian families. Two of these families reported a Romani background. All patients were clinically unaffected at the time of diagnosis and a galactose-restricted diet was initiated. Cataracts did not develop in the next 25-105 mo. Two further unrelated siblings born in Bosnia, where no neonatal screening for hypergalactosemia is performed, had cataract surgery at 4 and $5 \mathrm{y}$ of age, respectively. The diagnosis of GALK deficiency in these siblings was confirmed by measuring enzyme activity in erythrocytes. No clinical evidence for cataract was found in the parents of the affected children and the measurement of GALK activity was consistent with a heterozygous status.

DNA analysis of the GALK-deficient Turkish patient revealed compound heterozygosity for missense mutations at codons 142 (AGC $>$ ATC, serine $>$ isoleucine) and 144 in exon 3 of the galk1 gene, respectively (GGT $>$ TGT, glycine $>$ cysteine) (Fig. 1). Both parents were heterozygous for this double mutation, which was confirmed by allele-specific oligonucleotide hybridization (not shown). This double mutation was not detected in 20 healthy probands of different ethnic backgrounds.

DNA analysis of the eight Bosnian patients demonstrated a single $C C C>A C C$ (proline $>$ threonine) point mutation at codon 28 of exon 1 of the galk1 gene (not shown). This mutation abolished a CCCGAG AvaI site and restriction analysis of PCR fragments amplified from genomic DNA could

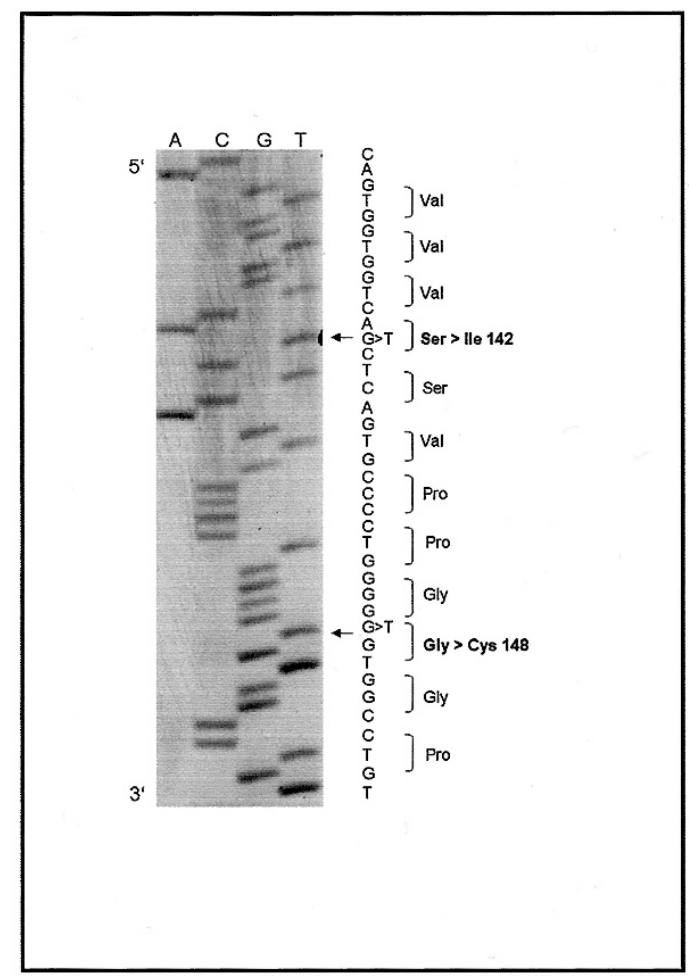

Figure 1. DNA sequence analysis of the galkl gene in the Turkish patient homozygous for the S142I/G148C double mutation. The arrows indicate the positions of the $\mathrm{G}>\mathrm{T}$ mutations at positions 425 and 442 of the galk1 cDNA. Val, valine; Ser, serine; Ile, isoleucine; Pro, proline, Gly, glycine; Cys, cysteine. 
thus be used to confirm the status of the patients and their parents, respectively (Fig. 2).

\section{DISCUSSION}

Since the cloning of the galk1 gene (13), 18 mutations have been identified in patients with GALK deficiency $(12,13,21$, 22). The functional relevance of the novel S142I/G148C double mutation reported here in a Turkish family is demonstrated by the lack of enzyme activity in the erythrocytes of the affected child and by the intermediate activity in the heterozygous parents. Both mutations are located close to a highly conserved region of the enzyme (Fig. 3), which represents a putative ATP-binding motif $(15,16,18)$. It is difficult to differentiate which of the two mutations is functionally more important, but it may be significant that the S142I mutation occurs two amino acid residues upstream of the putative ATP-binding domain, whereas the G148C amino acid change is directly located within the ATP-binding site. Furthermore, in the G148C mutant, the strong helix breaker glycine is substituted for cysteine, a feature that may favor the formation of a $\beta$-sheet and that may also trigger the formation of atypical sulfhydryl bonds. This putative conformational modification

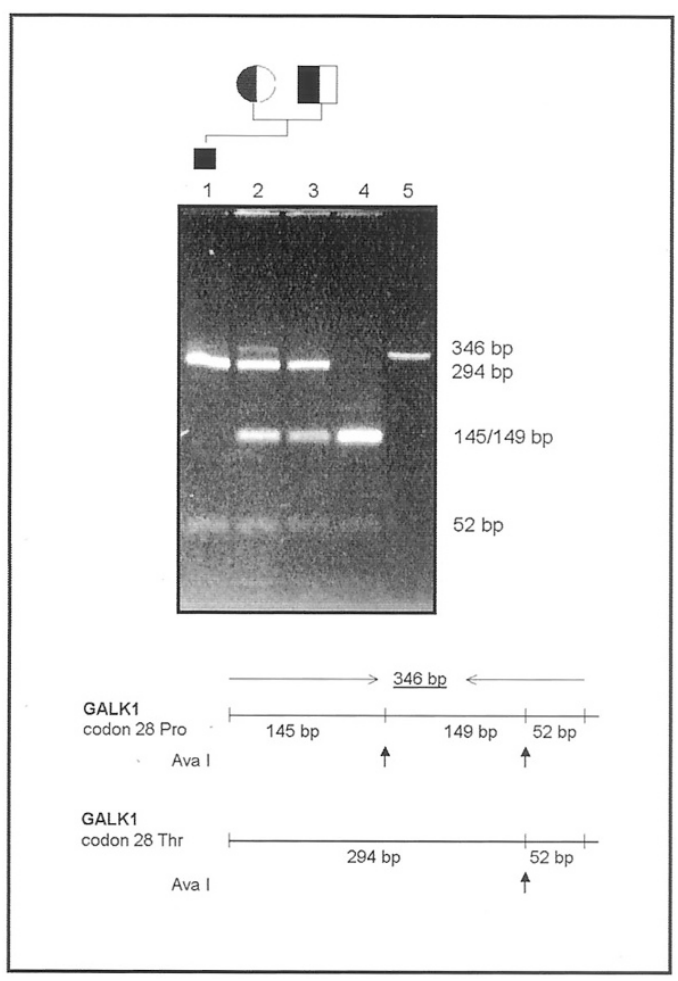

Figure 2. AvaI restriction analysis of a 346-bp galk1 PCR fragment encompassing the CCC $>$ ACC (P28T) mutation in a Bosnian family. The PCR fragment carrying the normal sequence [codon 28 proline (Pro)] contains two Aval restriction sites and is digested into a 52-bp fragment and two longer co-migrating fragments of $145 \mathrm{bp}$ and $149 \mathrm{bp}$. The PCR fragment carrying the mutation [codon 28 threonine (Thr)] has lost one of the two AvaI sites and is digested into a 52-bp fragment and a single larger abnormal fragment of 294 bp. The short 52-bp fragment is not affected by the mutation and was used as a control for complete digestion by the enzyme. Lane 1: DNA of the index patient; lanes 2 and 3: maternal and paternal DNAs; lane 4: normal DNA; lane 5: undigested DNA. may thus reduce the efficiency of ligand binding $(26,27)$ and abolish enzyme activity.

The relevance of the P28T mutation in the disease is also confirmed by the absence of enzyme activity in erythrocytes of the probands. This mutation is located just $\mathrm{N}$-terminally to a region that is phylogenetically highly conserved (Fig. 3) and is thought to be the active site of the enzyme $(15,16)$. The amino-terminal head of this critical segment is composed almost entirely of strong helix formers, suggesting an $\alpha$-helical conformation in this area. At position 28, the helical arrangement is interrupted by a proline. The rigid five-member ring of this amino acid does not fit within a straight stretch of an $\alpha$-helix and acts as a strong helix breaker. Because of its bulky shape, proline promotes reverse turns, so-called "hairpin bends" within proteins $(28-30)$. The substitution of threonine for proline at this position is expected to severely disrupt the secondary structure of the N-terminal portion of the enzyme, which probably interferes with the function of the active site in this area. The critical role of this part of the enzyme is further supported by the deleterious effect of a previously described V32M mutation in a homozygous GALK-deficient patient (13). The P28T mutation was identified in all of the nine GALK-deficient Bosnian children. A Romani background was reported by two of the five families. The finding of the same P28T mutation in five Bulgarian Romani families with GALK deficiency supports the view that P28T represents a founder mutation in this population (12). The only Turkish GALKdeficient newborn reported previously also bore the P28T mutation (22).

It is impossible to determine the exact incidence of GALK deficiency in the Bosnian population. A rough estimate can be based on the number of Bosnians $(\approx 30,000)$ that arrived in Berlin between 1991 and 1999. Although the ethnic background of refugees is not registered by the German immigration authorities, this group is estimated to include $\approx 5,000$

\section{galk-genes \\ amino acids $21-50$}

$\begin{array}{llll}\text { Human } & \text { / REEFGAEPEL AVSAPGRVNL IGEHTDYNQG / } \\ \text { E.coli } & / \text { ANAFGYPATH TIQAPGRVNL IGEHTDYNDG } \\ \text { L.helveticus } & / \text { EATSNEKAKD VFFSPGRINV IGEHTDYNGG } \\ \text { K.lactis } & / \text { DTD.DSRKFF ITRSPGRVNL IGEHIDYCGF } \\ \text { S.lividans } & / \text { CGRRAAEEEL AVSAPGRVNL IGEHTDYNDG / }\end{array}$

amino acids $130-160$

$\begin{array}{lll}\text { Human } & \text { / A PLP.GESAVV VSSVPLGGGL SSSASLEVAT } \\ \text { E.coli } & / \text { N SFG. GVDMVI SGNVPQGAGL SSSASLEVAV } \\ \text { L.helveticus } & / \text { D } & \text { GIDHGFNLYI EANLPSGSGL SSSAAIEMLM } \\ \text { K.lactis } & / \text { K } & \text { GPVHGMEIYV KGDIPSGGGL SSSAAFICAV } \\ \text { S.lividans } & / & \text {. . LTGADVHL ASTVPSGAGL SSSAALEVRP }\end{array}$

Figure 3. Phylogenetic comparison of galk genes of different organisms. The figure compares the human galactokinase gene (human) with that of E. coli, Lactobacillus helveticus, Kluyveromyces lactis, and S. lividans. Amino acids 21-50 and 130-160 are shown. Phylogenetically conserved amino acids are highlighted. The amino acids affected by the mutations reported here are in bold type and underlined. 
Romani. The birth rate is unknown, but the occurrence of 8 newborns with GALK deficiency in a population of 5,00030,000 in a period of $9 \mathrm{y}$ suggests that this disorder is relatively common in this group. In comparison, during the same period, 27 patients with phenylketonuria were identified by the neonatal screening of the ethnically mixed Berlin population of 3,500,000 (Mönch E, unpublished data). These figures suggest that GALK deficiency in Bosnians may be about 35 times more frequent than phenylketonuria in the Berlin population. The relatively high incidence of GALK deficiency in Bosnians in general and in Romani in particular is supported by previous reports of GALK deficiency in Romani families from Bavaria, Austria, Switzerland, and Bulgaria (10-12, 31).

Screening for GALK deficiency is technically simple, and the identification of this disorder in the newborn period enables the prevention of cataracts (3). Therefore, it may be warranted to include investigations of GALK deficiency in newborn screening programs for high-risk populations such as those from southeastern Europe. It might be questioned whether the expense of screening and the adherence to a galactose-free diet is preferential to cataract surgery. However, it must be considered that surgical management of cataracts results in a significant aphakic refractive error and most surgical techniques do not enable subsequent accommodation. There are also possible long-term complications of surgery such as inflammatory changes, secondary membranes, glaucoma, retinal detachment, and changes of the axial length of the eye $(32,33)$. The patients described here were treated with a galactose-free diet and did not develop cataracts. In conclusion, we propose that GALK deficiency should be included in the neonatal screening program of high-risk populations.

Acknowledgment. The authors thank the Pediatric Intensive Care Unit of the Charité, Station 25, for help and encouragement.

\section{REFERENCES}

1. Gitzelmann R 1965 Deficiency of erythrocyte galactokinase in a patient with galactose diabetes. Lancet 2:670-671

2. Stambolian D 1988 Galactose and cataract. Surv Ophthalmol 32:333-349

3. Segal S, Holten JG, Walter JH, Tyfield LA 2001 Galactosemia. In: Scriver CR, Beaudet AL, Sly WS, Valle D (eds) The Metabolic and Molecular Bases of Inherited Disease, 8th Ed. McGraw-Hill, New York, pp 453-480

4. Prachal JT, Conrad ME, Skalka HW 1978 Association of presenile cataracts with heterozygosity for galactosaemic states and with riboflavin deficiency. Lancet $1: 12-13$

5. Stambolian D, Scarpino-Myers V, Eagle RC, Hodes B, Harris H 1986 Cataracts in patients heterozygous for galactokinase deficiency. Invest Ophthalmol Vis Sci 27:429-433

6. Skalka HW, Prachal JT 1980 Presenile cataract formation and decreased activity of galactosemic enzymes. Arch Ophthalmol 98:269-273
7. Oberman AE, Wilson WA, Frasier SD, Donnell GN, Bergren WR 1972 Galactokinase-deficiency cataracts in identical twins. Am J Ophthalmol 74:887-892

8. Mayes JS, Guthrie R 1968 Detection of heterozygotes for galactokinase deficiency in a human population. Biochem Genet 2:219-230

9. Segal S, Berry GT 1995 Disorders of galactose metabolism. In: The Metabolic and Molecular Bases of Inherited Disease. New York, McGraw-Hill, pp

10. Gitzelmann R 1967 Hereditary galactokinase deficiency, a newly recognized cause of juvenile cataracts. Pediatr Res 1:14-23

11. Thalhammer O, Gitzelmann R, Pantlitschko M 1968 Hypergalactosemia and galactosuria due to galactokinase deficiency in a newborn. Pediatrics 42:441-445

12. Kalaydjieva L, Perez-Lezaun A, Angelicheva D, Onengut S, Dye D, Bosshard NU, Jordanova A, Savov A, Yanakiev P, Kremensky I, Radeva B, Hallmayer J, Markov A, Nedkova V, Tournev I, Aneva L, Gitzelmann R 1999 A founder mutation in the GK1 gene is responsible for galactokinase deficiency in Roma (Gypsies). Am J Hum Genet 65:1299-1307

13. Stambolian D, Ai Y, Sidjanin D, Nesburn K, Sathe G, Rosenberg M, Bergsma DJ 1995 Cloning of the galactokinase cDNA and identification of mutations in two families with cataracts. Nat Genet 10:307-317

14. Bergsma DJ, Ai Y, Skach WR, Nesburn D, Anoia E, Van Horn S, Stambolian D 1996 Fine structure of the human galactokinase GALK1 gene. Genome Res 8:980-985

15. Debouck C, Riccio A, Schumperli D, McKenney K, Jeffers J, Hughes C, Rosenberg M 1985 Structure of the galactokinase gene of E. coli, the last (?) gene of the gal operon. Nucleic Acids Res 13:1841-1853

16. Citron BA, Donelson JE 1984 Sequence of the Saccharomyces GAL region and its transcription in vivo. J Bacteriol 158:269-278

17. Adams CW, Fornwald JA, Schmidt FJ, Rosenberg M, Brawner ME 1988 Gene organization and structure of the Streptomyces lividans gal operon. J Bacteriol 170:203-212

18. Tsay YH, Robinson GW 1991 Cloning and characterization of ERG8, an essential gene of Saccharomyces cerevisiae that encodes phosphomevalonate kinase. Mol Cell Biol 11:620-631

19. Lee RT, Peterson CL, Calman AF, Herskowitz I, O’Donnell JJ 1992 Cloning of a human galactokinase gene (GK2) on chromosome 15 by complementation in yeast. Proc Natl Acad Sci U S A 89:10887-10891

20. Ai Y, Basu M, Bergsma DJ, Stambolian D 1995 Comparison of the enzymatic activities of human galactokinase GALK1 and a related human galactokinase protein GK2. Biochem Biophys Res Commun 212:687-691

21. Asada M, Okano Y, Imamura T, Suyama I, Hase Y, Isshiki G 1999 Molecular characterization of galactokinase deficiency in Japanese patients. J Hum Genet 44:377-382

22. Kolosha V, Anoia E, de Cespedes C, Gitzelmann R, Shih L, Casco T, Saborio M, Trejos R, Buist N, Tedesco T, Skach W, Mittelmann O, Ledel D, Huang K, Stambolian D 2000 Novel mutations in 13 probands with galactokinase deficiency. Hum Mutat 15:447-453

23. Ng WG, Kawamura M, Donnell GN 1983 Galactosemia screening: methodology and outcome from worldwide data collection. In: Therrall Jr BL (ed) Advances in Neonatal Screening. Elsevier, Amsterdam, pp 243-249

24. Shin YS 1990 Galactose metabolites and disorders of galactose metabolism. In: Hommes FA (ed) Techniques in Diagnostic Human Biochemical Genetics. WileyLiss, New York, pp 267-284

25. Thein SL, Hinton J 1991 A simple and rapid method of direct sequencing using Dynabeads. Br J Haematol 79:113-115

26. Chon PY, Fasman GD 1974 Prediction of protein conformation. Biochemistry 13:222-244

27. Creighton TE 1985 Energetics of protein structure and folding. Biopolymers 24:167182

28. Chothia C 1984 Principles that determine the structure of proteins Annu Rev Biochem 53:537-572

29. Richardson JS 1981 The anatomy and taxonomy of protein structure. Adv Protein Chem 34:167-339

30. Chou PY, Fasman GD 1974 Prediction of protein conformation. Biochemistry 13:222-244

31. Kaloud H, Sitzmann FC 1974 The galactokinase deficiency in two human populations: Styria (Austria) and Franconia (Bavaria): a comparative investigation on gene frequency. Z Kinderheilk 116:185-192

32. Nelson LB 1984 Diagnosis and management of cataracts in infancy and childhood. Ophthalmic Surg 15:688-97

33. Morgan KS 1993 Cataract surgery and intraocular lens implantation in children. Curr Opin Ophthalmol 4:54-60 